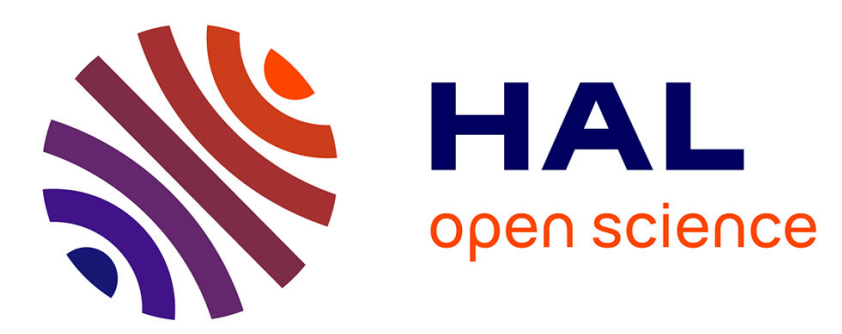

\title{
A new strange Archaeorthoptera from the Moscovian of Avion (France) (Insecta, Polyneoptera)
}

\author{
André Nel, Patrick Roques
}

\section{To cite this version:}

André Nel, Patrick Roques. A new strange Archaeorthoptera from the Moscovian of Avion (France) (Insecta, Polyneoptera). Historical Biology, 2021, 34 (9), pp.1769-1771. 10.1080/08912963.2021.1978082 . hal-03356138

\section{HAL Id: hal-03356138 \\ https://hal.sorbonne-universite.fr/hal-03356138}

Submitted on 27 Sep 2021

HAL is a multi-disciplinary open access archive for the deposit and dissemination of scientific research documents, whether they are published or not. The documents may come from teaching and research institutions in France or abroad, or from public or private research centers.
L'archive ouverte pluridisciplinaire HAL, est destinée au dépôt et à la diffusion de documents scientifiques de niveau recherche, publiés ou non, émanant des établissements d'enseignement et de recherche français ou étrangers, des laboratoires publics ou privés. 
Historical Biology

Manuscript DOI: 10.1080/08912963.2021.1978082

(3)

A new strange Archaeorthoptera from the Moscovian of Avion (France) (Insecta, Polyneoptera)

\section{André Nel ${ }^{\mathrm{a}}$ and Patrick Roques ${ }^{\mathrm{b}}$}

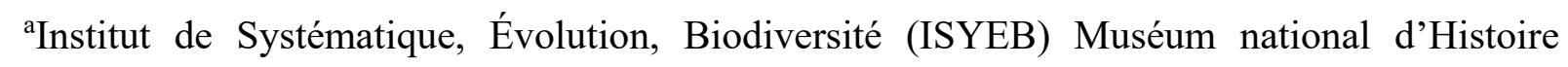
naturelle, CNRS, Sorbonne Université, EPHE, Université des Antilles, CP50, 57 rue Cuvier 75005 Paris, France

b2 Chemin des Processions, 93360 Neuilly Plaisance, France.

anel@mnhn.fr; https://orcid.org/0000-0002-4241-7651

patrick.roques93@,wanadoo.fr; https://orcid.org/0000-0002-8721-9763

\section{ABSTRACT}

A new archaeorthopteran genus and species, Avionugonioneura jouaulti, is described from the Moscovian of the Avion in Northern France. It shows several strong similarities, with the two genera Contracladus (Pennsylvanian) and Nugonioneura (early Permian), viz. a simple vein M emerging anteriorly from $\mathrm{M}+\mathrm{CuA}+\mathrm{CuPa}$ and an anteriorly branched $\mathrm{CuA}+\mathrm{CuPa}$, which are putative synapomorphies, suggesting a possible attribution to the family Nugonioneuridae. This discovery confirms the very important diversity of the Archaeorthoptera in the outcrop of Avion.

\section{KEYWORDS}


Insecta; Polyneoptera; ?Nugonioneuridae; early late Carboniferous; diversity

\section{Introduction}

For a Moscovian outcrop, The Konservat-Lagerstätte of Avion (Northern France) is especially rich in polyneopteran insects of the superorder Archaeorthoptera (so-called 'orthopteroid' insects), with no less than eight genera and nine species: Aviogramma gracilis Prokop et al., 2014 (plus another Caloneurodea), Aviocladus pectinatus Prokop et al., 2014, Aviohapaloptera bethouxi Prokop et al., 2014, Aviologus duquesnei Coty et al., 2014, Cacurgus avionensis Schubnel et al., 2020, Beloatta duquesnei Nel et al., 2021, cf. Tococladus sp. (Coty et al. 2014; Prokop et al. 2014; Schubnel et al. 2020; Nel et al. 2020).

Here we describe a further new genus and species belonging to a family different of those previously recorded, confirming the impressive diversity of the clade in this outcrop.

\section{Material and methods}

The fossil was found by one of us (P.R.) in the slag heap of Avion. It was examined under a Nikon SMZ1500 and photographed with an AmScope camera MU900.

We follow the wing venation terminology of Béthoux and Nel (2002).

Wing vein terminology: $\mathrm{CuA}$, cubitus anterior; $\mathrm{CuP}$, cubitus posterior; $\mathrm{CuPa}$, anterior branch of $\mathrm{CuP}$; $\mathrm{CuPb}$, posterior branch of $\mathrm{CuP} ; \mathrm{M}$, median vein; $\mathrm{PCu}$, postcubital vein; $\mathrm{RA}$, radius anterior; RP, radius posterior; $\mathrm{ScP}$, subcosta posterior.

Systematic palaeontology

Superorder Archaeorthoptera Béthoux and Nel, 2002

Family ?Nugonioneuridae Carpenter, 1976

Avionugonioneura gen. nov. 
Type species

Avionugonioneura jouaulti sp. nov.

Diagnosis

Forewing characters only. $\mathrm{CuPa}$ ending into $\mathrm{M}+\mathrm{CuA}$ and not in a free $\mathrm{CuA}$; no $\mathrm{CuPa}$, vein

$\mathrm{M}+\mathrm{CuA}+\mathrm{CuPa}$ anteriorly pectinate; $\mathrm{ScP}$ ending into costa; short posterior branches of

$\mathrm{CuA}+\mathrm{CuPa}$; five simple branches of $\mathrm{RP} ; \mathrm{M}$ simple and strictly parallel to branches of $\mathrm{RP}$ and

to first anterior branch of $\mathrm{CuA}+\mathrm{CuPa}$; area between RA and RP broad with two rows of cells.

Etymology

Named after the outcrop of Avion and the genus name Avionugonioneura. Gender feminine.

64

Avionugonioneura jouaulti sp. nov.

(Fig. 1)

67

Zoobank xxxx

68

69

Etymology

70

Named after our friend and colleague Corentin Jouault, for his contribution to

71 Palaeoentomology.

72

73

Type material

74

MNHN.F.A71353 (two nearly complete forewings overlapped at rest), stored at the Muséum National d'Histoire Naturelle, Paris, France. 
Type locality

'Terril Nº7', Avion, Pas-de-Calais, France.

79

Stratigraphic occurrence

Moscovian (Westphalian C/D equivalent to Bolsovian/Asturian).

Diagnosis

As for the genus by monotypy.

Description

Forewing elongate, $16.0 \mathrm{~mm}$ long, $5.0 \mathrm{~mm}$ wide; ScP reaching anterior wing margin at $8.7 \mathrm{~mm}$ from wing base; costal area rather narrow, $0.6 \mathrm{~mm}$ wide with no visible veinlet; a series of simple short crossveins in area between $\mathrm{ScP}$ and R; RP separating from RA $4.4 \mathrm{~mm}$ from wing base; area between RA and RP broad, $0.7 \mathrm{~mm}$ wide, with two rows of cells in its distal part, apically narrower; RA with a series of short, more or less curved anterior veinlets between it and anterior wing margin; apex of RA $2.4 \mathrm{~mm}$ of wing apex; RP with five posterior branches, three of them being forked again distally, parallel to M; RA and RP approximate in apical parts; and simple in its preserved part; anal veins not preserved. 
102

103

104

105

106

107

108

109

110

111

112

113

114

115

116

117

118

119

120

This fossil is a pair of forewings in life position. It belongs to the Archaeorthoptera because of the following characters (Béthoux and Nel 2002): CuP differentiated into concave CuPa and $\mathrm{CuPb}$; a common stem $\mathrm{R}+\mathrm{M}+\mathrm{CuA}$, from which $\mathrm{M}+\mathrm{CuA}$ separates distally; $\mathrm{CuPa}$ ending into $\mathrm{M}+\mathrm{CuA}$. Avionugonioneura gen. nov. does not fall into the Panorthoptera because CuPa is not differentiated into two branches $\mathrm{CuPa} \alpha$ and $\mathrm{CuPa} \beta$; MA1 and MA2 cannot be differentiated. It has a very peculiar vein $\mathrm{M}+\mathrm{CuA}+\mathrm{CuPa}$, with two strong and simple anterior branches, which is rarely found among the Archaeorthoptera but also present in the Paoliida for $\mathrm{CuA}$ only (Prokop et al. 2014a). Similar pectinations are found in the Cnemidolestodea sensu Béthoux (2005), but with the important difference in the first branch being itself forked several times. Another difference to the members of Cnemidolestodea is the vein $\mathrm{CuPa}$ ending into $\mathrm{M}+\mathrm{CuA}$ in Avionugonioneura gen. nov., while it ends into $\mathrm{CuA}$ in the Cnemidolestodea. Tow Cnemidolestodea are already known from Avion, viz. Aviocladus Prokop et al., 2014 that differs from Avionugonioneura gen. nov. in ScP ending into R, and base of RP in a much distal position (Prokop et al. 2014b); and Piesbergopterum avionensis Nel and Roques, 2021 that differs from Avionugonioneura gen. nov. in the presence of a specialized area between an anterior branch of $\mathrm{M}$ and a posterior branch of the same vein (Nel and Roques, 2021). Few cases of Archaeorthoptera with $\mathrm{CuPa}$ ending into $\mathrm{M}+\mathrm{CuA}$ and not in a free $\mathrm{CuA}$ are known. It is the case for Bruaylogus magnificus Coty et al., 2014, but this taxon has a CuPa $\beta$ as panorthopteran synapomorphy, and no anterior pectination of $\mathrm{CuA}+\mathrm{CuPa}$ (Coty et al. 2014; $\mathrm{Gu}$ et al. 2017). Nugonioneura Tillyard, 1937 (N. problematica Tillyard, 1937 known from the Lower Permian of Elmo in Kansas, U.S.A.) (Tillyard 1937; Aristov 2020, p. 6, Figs 3, 4) and Contracladus impar Dvořák et al., 2021 (Pennsylvanian of Piesberg, Germany) also have no $\mathrm{CuPa} \beta$, a simple $\mathrm{M}$ anteriorly emerging from vein $\mathrm{M}+\mathrm{CuA}+\mathrm{CuPa}$, and an anterior branch of $\mathrm{CuA}+\mathrm{CuPa}$ parallel to $\mathrm{M}$, as in Avionugonioneura gen. nov. Both differ from 
Avionugonioneura gen. nov. in ScP ending into RA, the presence of an angle in M below base of RP so that these two veins approximate, no posterior branch of $\mathrm{CuA}+\mathrm{CuPa}$, shorter anterior branches of $\mathrm{CuA}+\mathrm{CuPa}$. Nugonioneura has only three simple branches of RP instead of five with some being forked again more distally in Avionugonioneura gen. nov. and Contracladus. $\mathrm{M}$ is distally forked in Contracladus, instead of being simple as in Avionugonioneura gen. nov. and Nugonioneura.

As a conclusion, Contracladus, Nugonioneura, and Avionugonioneura gen. nov. can only be considered as Archaeorthoptera of uncertain affinities. A new phylogenetic analysis will be necessary to clarify their positions, even if they possibly all belong to the same archaeorthopteran family Nugonioneuridae that would be characterized by the putative apomorphies: ' $\mathrm{CuPa}$ ending into $\mathrm{M}+\mathrm{CuA}$ ', a 'simple $\mathrm{M}$ anteriorly emerging from $\mathrm{M}+\mathrm{CuA}+\mathrm{CuPa}$ ', and 'presence of a simple anterior branch of $\mathrm{CuA}+\mathrm{CuPa}$ '.

Remarks. Coty et al. (2014: 464, fig. 1) described and figured a wing fragment they attributed to a 'cf. Tococladus sp.' (Cnemidolestodea Tococladidae). It strongly resemble the wing apex of Avionugonioneura gen. nov. in the number of branches of RP, simple $\mathrm{M}$ and anterior branches of $\mathrm{CuA}+\mathrm{CuPa}$, and RA and RP strongly approximating distally. The only difference is the area between RA and RP narrower in the putative 'cf. Tococladus sp.' than in Avionugonioneura gen. nov. Numerous Palaeozoic wings of Polyneoptera have very similar patterns of venations in their distal parts. They can be discriminated and attributed to precise clades only on the basis of the basal halves of the wings.

Rasnitsyn and Aristov (2021: 151) indicated that in Tococladus garrici Béthoux et al., 2003, the vein ' $\mathrm{CuPa}$ ' is convex, after the original photograph in Béthoux et al. (2003: fig. 4), suggesting that the attribution of the Tococladidae to the Archaeorthoptera could be not wellgrounded. But the original photograph shows a $\mathrm{CuPa}$ of 'intermediate' convexity compared to 
those of the convex $\mathrm{M}+\mathrm{CuA}$ and the concave stem of $\mathrm{CuP}$. Also Béthoux et al. (2003) did not indicate anything about the convexity of this vein. This uncertainness in the determination of the convexity of the vein $\mathrm{CuPa}$ is due to fossilization, but it is clear that this vein has a diameter and shape different of the more distal vein $\mathrm{CuA}+\mathrm{CuPa}$, supporting that it is a branch of $\mathrm{CuP}$ and not $\mathrm{CuA}$. Thus the argument of Rasnitsyn and Aristov (2021) does not stand.

\section{Acknowledgements}

We sincerely thank Mr. Stéphane Carlier and Mr. Patrick Wypych, Eiffage Route Nord Est, for the kind authorization to collect fossil insects in the terril of Avion.

\section{References}

Aristov DS. 2020. Revision of the genera Heteroptilon, Nugonioneura and Opistocladus from the Lower Permian of USA (Insecta: Cnemidolestida: Tillyardembiidae, Nugonioneuridae and Parmapteridae). Far Eastern Entomologist 401:1-9.

Béthoux, O. 2005. Cnemidolestodea (Insecta): an ancient order reinstated. Journal of Systematic Palaeontology 3:403-408. https://doi.org/10.1017/S147720190500163X

Béthoux O, Nel A. 2002. Venation pattern and revision of Orthoptera sensu nov. and sister groups. Phylogeny of Palaeozoic and Mesozoic Orthoptera sensu nov. Zootaxa 96:1-88.

\section{https://doi.org/10.11646/zootaxa.96.1.1}

Béthoux O, Nel A, Galtier J, Lapeyrie J, Gand G. 2003. A new species of Tococladidae Carpenter, 1966 from the Permian of France (Insecta: Archaeorthoptera). Geobios 36:275283. https://doi.org/10.1016/S0016-6995(03)00030-5

Carpenter FM. 1976. The Lower Permian insects of Kansas. Part 12. Protorthoptera (continued), Neuroptera, additional Palaeodictyoptera, and families of uncertain position. Psyche 83:336-376. https://doi.org/10.1155/1976/932123 
Coty D, Háva J, Prokop J, Roques P, Nel A. 2014. New archaeorthopteran insects from the Late Carboniferous of the Nord and Pas-de-Calais basins in northern France (Insecta: Cnemidolestodea, Panorthoptera).

Zootaxa $3878: 462-470$. https://doi.org/10.11646/zootaxa.3878.5.4

Dvořák T, Pecharová M, Leipner A, Nel A, Prokop J. 2021. New archaeorthopteran insects from the Pennsylvanian of Piesberg reveal unexpected mosaic of morphological traits and colouration pattern of the tegmina. Historical Biology https://doi.org/10.1080/08912963.2020.1867127

Gu J-J, Béthoux O, Ren D. 2017. A new, rare and distinctive species of Panorthoptera (Insecta, Archaeorthoptera) from the Upper Carboniferous of Xiaheyan (Ningxia, China). Fossil Record 20:253-257. https://doi.org/10.5194/fr-20-253-2017

Nel A, Garrouste R, Roques P. 2020. The first representative of the archaeorthopteran family Eoblattidae in the Konservat-Lagerstätte of Avion (France) (Insecta: Polyneoptera). Palaeoentomology 3:552-555. https://doi.org/10.11646/palaeoentomology.3.6.3

Nel A, Roques P. 2021. The second species of the cnemidolestid genus Piesbergopterum from the Upper Carboniferous of Avion, Northern France (Archaeorthoptera: Cnemidolestidae). Palaeoentomology 4:323-325. https://doi.org/10.11646/palaeoentomology.4.4.6

Prokop J, Krzeminski W, Krzeminska E, Hörnschemeyer T, Ilger J-M, Brauckmann C, Grandcolas P, Nel A. 2014a. Late Palaeozoic Paoliida is the sister group of Dictyoptera (Insecta: Neoptera). Journal of Systematic Palaeontology 12:601-622. https://doi.org/10.1080/14772019.2013.823468

Prokop J, Roques P, Nel A. 2014b. New non-holometabolous insects from Pennsylvanian of Avion locality in Pas-de-Calais, France (Insecta: 'Exopterygota'). Alcheringa 38:155-169. $\underline{\text { https://doi.org/10.1080/03115518.2014.848620 }}$ 
Rasnitsyn AP, Aristov DS. 2021. Review of the Family Tococladidae Carpenter (Insecta: Eoblattida) from the Permian of North America and Europe. Paleontological Journal 55:151-156. https://doi.org/10.1134/S003103012102012X

Schubnel T, Roberts D, Roques P, Garrouste R, Desutter-Grandcolas L, Nel A. 2020. Moscovian fossils shed light on the enigmatic polyneopteran families Cacurgidae and Eoblattidae (Insecta: 'Eoblattida', Archaeorthoptera). Journal of Systematic Palaeontology 18:499-511. https://doi.org/10.1080/14772019.2019.1627595

Tillyard RJ. 1937. Kansas Permian insects. 17. The order Megasecoptera and additions to the Palaeodictyoptera, Odonata, Protoperlaria, Copeognatha and Neuroptera. American Journal of Science (5) 33:81-110. https://doi.org/10.2475/ajs.s5-33.194.81

Figure 1. Avionugonioneura jouaulti gen. et sp. nov., holotype MNHN.F.A71353. (A) photograph of habitus; (B) forewing reconstruction, arrowhead: $\mathrm{M}+\mathrm{CuA}$, arrow: $\mathrm{CuPa}$. Scale bars $=1 \mathrm{~mm}$. 

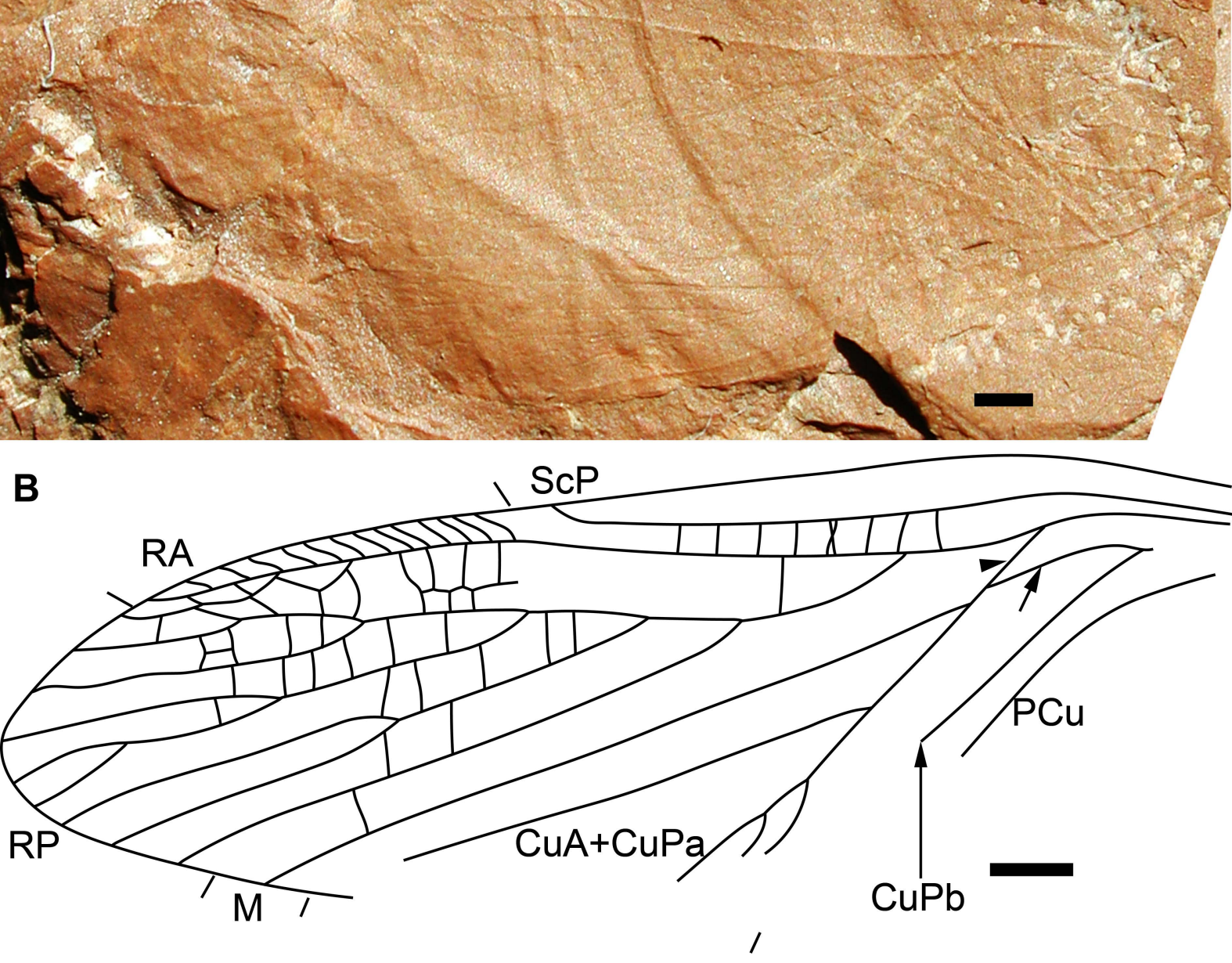